\title{
Isolation of Emiliania huxleyi viruses from the Gulf of Maine
}

\author{
James M. Vaughnn ${ }^{1, *}$, William M. Balch ${ }^{2}$ James F. Novotny ${ }^{1}$, Cathy L. Vining ${ }^{1}$, \\ Christopher D. Palmer ${ }^{1}$, David T. Drapeau ${ }^{2}$, Emily Booth ${ }^{2}$, James M. Vaughn Jr. ${ }^{1}$, \\ Dustin M. Kneifel ${ }^{1}$, Allen L. Bell ${ }^{1}$
}

${ }^{1}$ Department of Microbiology, College of Osteopathic Medicine, University of New England, Biddeford, Maine 04005, USA

${ }^{2}$ Bigelow Laboratory for Ocean Sciences, PO Box 475, W. Boothbay Harbor, Maine 04575, USA

\begin{abstract}
Viruses infective to the marine coccolithophore Emiliania huxleyi were isolated from waters of the Gulf of Maine during May and June of 2004, a period when ambient E. huxleyi concentrations were minimal. Three DNA-containing, ether-insensitive virus isolates possessed icosahedral symmetry, and were 130 to $160 \mathrm{~nm}$ in diameter. All isolates caused complete lysis of host cultures within $4 \mathrm{~d}$, produced large plaques on host lawns in agarose and were stable at $-72^{\circ} \mathrm{C}$ for at least 18 mo. Originally propagated on the 88E strain of E. huxleyi, none of the viral isolates were able to infect related host strains, including several that were native to the Gulf of Maine. They were also noninfectious for strains of Synechococcus and Micromonas pusilla. One-step growth studies showed a high level of virus propagation during the first $24 \mathrm{~h}$, a period when corresponding host populations were quite stable. This finding led us to speculate that virus progeny might be leaking from intact hosts during this period, with eventual host lysis occurring later. The viruses appeared to be highly infectious, with multiplicities of infection (MOI) as low as $10^{-5}$ clearing host cultures within $96 \mathrm{~h}$. Similar efficiencies were seen when host concentrations were as low as $10^{2} \mathrm{cells} \mathrm{ml}^{-1}$. An additional isolate, which appeared to possess similar characteristics to the above viruses, exhibited an unusually rapid growth cycle, with host lysis occurring within $5 \mathrm{~h}$ post infection.
\end{abstract}

KEY WORDS: Emiliania huxleyi $\cdot$ Viruses $\cdot$ Growth dynamics

Resale or republication not permitted without written consent of the publisher

\section{INTRODUCTION}

Coccolithophores are ubiquitous calcifying algae of the class Prymnesiophyceae which form $2 \mu \mathrm{m}$ diameter scales made of $\mathrm{CaCO}_{3}$ (Thierstein \& Young 2004). This algal class has global significance to the carbon cycle since its members fix dissolved inorganic carbon into $\mathrm{CaCO}_{3}$ which is subsequently buried on the sea floor (Broecker \& Peng 1982). This represents one of the major pathways that dissolved inorganic carbon (which is in equilibrium with atmospheric $\mathrm{CO}_{2}$ ) is sequestered for geological time in the sediments. The other unique aspect of these organisms (making them particularly useful for satellite remote sensing) is that their $\mathrm{CaCO}_{3}$ scales are highly reflective and easily detectable from space (Gordon et al. 2001, Balch et al.
2005). The Gulf of Maine (GOM) has abundant coccolithophores, mainly of the species Emiliania huxleyi, with documented mesoscale blooms (based on satellite imagery dating back to the 1980s, Holligan et al. 1983). These blooms have covered half the GOM, encompassing areas of 100000 to $200000 \mathrm{~km}^{2}$ (Balch et al. 1991). Due to the sheer magnitude of these events, and their global significance, there has been great interest in factors that control E. huxleyi blooms, such as grazing, sinking and viral infection.

Viruses represent the most abundant form of life in the oceans (Børsheim et al. 1990, Suttle \& Chan 1993, Furhman 1999), with concentrations ranging from $10^{3}$ to as high as $10^{10} \mathrm{l}^{-1}$ in eutrophic regions (Bergh et al. 1989, Bratbak et al. 1993). It has been suggested that viruses may play an important role in the ecological 
control of planktonic microorganisms (Suttle et al. 1990, Suttle \& Chan 1993, Castberg et al. 2001). It has become apparent that bloom dynamics can be modulated by viruses. Sieburth et al. (1988) described a possible viral etiology in the decline of Aureococcus anophagefferens (brown tide). Similarly, a virus role was postulated in the decline of a red tide bloom in Japan (Nagasaki et al. 1994). Here, more than $10 \%$ of the algal population (Heterosigma akashiwo) was found to contain mature virus particles. Studies by Suttle \& Chan $(1993,1994)$ and Waterbury \& Valois (1993) indicated that cyanophage abundance covaried with that of its specific host (Synechococcus spp.). Several workers have reported the isolation of Emiliania huxleyi-specific viruses. Bratbak et al. (1995), studying the collapse of an E. huxleyi bloom in a Norwegian fjord, noted an inverse relation between viral abundance and E. huxleyi concentration, concluding that viruses were largely responsible for the termination of the bloom. While studying a bloom of E. huxleyi in the North Sea, Brussaard et al. (1996) observed that up to $50 \%$ of the cells were infected with virus-like particles by the end of the bloom. More recent studies have focused on the characterization of several of these isolates (Wilson et al. 2002, Schroeder et al. 2003). To date, most viruses have been isolated during $E$. huxleyi blooms or during a period of bloom collapse.

In the present study, we describe the isolation and partial characterization of Emiliania huxleyi viruses from waters of the GOM. We note that isolations were made in the absence of any host bloom.

\section{MATERIALS AND METHODS}

Study site and sample collection. Water samples for viral analysis were collected from the MS 'Scotia Prince', which traveled daily between Portland, ME, and Yarmouth, NS. A complete description of the ship of opportunity, measurements and the sampling transect through the GOM is detailed in Balch et al. $(2004,2008)$. Seawater samples pertinent to this report were collected on 12 May and 4 June 2004 from sampling stations located near the Scotian Shelf Front at $43^{\circ} 43.665^{\prime} \mathrm{N}$, $67^{\circ} 09.22^{\prime} \mathrm{W}$ and $43^{\circ} 43.846^{\prime} \mathrm{N}, 067^{\circ} 15.229^{\prime} \mathrm{W}$, respectively, from a depth of approximately $3 \mathrm{~m}$. Samples ( $\sim$ to 5 l) were collected in sterile, polycarbonate bottles (Nalgene) and stored in the dark at $4^{\circ} \mathrm{C}$ until analysis a few days later.

Host cultures. Emiliania huxleyi strains 88E and 02E (clones f6 and f11; now designated CCMP 2231 and 2230, respectively) were used in the present study. All remaining E. huxleyi strains were obtained from the Provasoli-Guillard National Center for Culture Of Marine Phytoplankton (CCMP), including strains
CCMP 370, 373, 374, 378, 379 and 1516, Synechococcus strain CCMP 1333 and Micromonas pusilla strains CCMP 1195 and 1545. E. huxleyi and M. pusilla were grown in f/2 medium (Guillard 1975 ) at $17^{\circ} \mathrm{C}$ under a $14 \mathrm{~h}$ light:10 h dark cycle in a Precision Scientific lowtemperature illuminated incubator Model 818 ( 8 $\mu \mathrm{mol}$ $\mathrm{m}^{-2} \mathrm{~s}^{-1}$ ). Synechococcus strain CCMP 1333 was propagated in f/2 medium at $22^{\circ} \mathrm{C}$ under a $14 \mathrm{~h}$ light:10 h dark cycle in a Revco BOD10 refrigerated incubator fitted with a $15 \mathrm{~W}$ clear incandescent light.

Virus isolation from seawater. Viruses were isolated from seawater samples using a modification of an enrichment technique used previously in our laboratory for the isolation of viruses of marine heterotrophic and photosynthetic bacteria (Balch et al. 2000). Briefly, $100 \mathrm{ml}$ volumes of $3 \times$, f/2 growth medium were inoculated with $200 \mathrm{ml}$ of either $0.45 \mu \mathrm{m}$ (Millipore, HAWP 04700) or $0.22 \mu \mathrm{m}$ (Millipore, GSWP 04700) filtered seawater. All filters were pretreated with $2 \%$ fetal calf serum (Atlanta Biologicals) to decrease the likelihood of virus adsorbing to them. Concentrated $(5800 \times g$ for $20 \mathrm{~min}$ at $4^{\circ} \mathrm{C}$ in a Sorvall $\mathrm{RC}-2 \mathrm{~B}$ refrigerated superspeed centrifuge), exponentially growing Emiliania huxleyi 88E was then added to each reaction flask at a final concentration of $\sim 1 \times 10^{5} \mathrm{ml}^{-1}$. Seawater samples were also assayed directly for virus particles. Following filtration through fetal calf serum-treated ( $2 \% \mathrm{v} / \mathrm{v})$ $0.22 \mu \mathrm{m}$ Millipore filters, $5 \mathrm{ml}$ volumes were inoculated into $100 \mathrm{ml}$ cultures of exponentially growing E. huxleyi 88E. Control and experimental flasks of E. huxleyi $88 \mathrm{E}$ cells were incubated for 2 wk under the growth conditions described and host numbers were assayed daily. Experimental flasks showing host lysis were filtered through serum-treated, $0.22 \mu \mathrm{m}$ filters, and tested for lytic activity on fresh cultures of exponentially growing host cells.

Virus enumeration. Direct counts of virus-like particles in lysates were conducted using the SYBR Green I fluorescent staining method developed by Noble \& Fuhrman (1998). We also adapted a most probable number (MPN) assay to assess agent viability. Briefly, 24 -well plates were inoculated with $0.5 \mathrm{ml}$ of $\mathrm{f} / 2$ medium and $1 \mathrm{ml}$ of an exponential phase culture of Emiliania huxleyi 88E. Virus stocks were serially diluted and $0.5 \mathrm{ml}$ volumes inoculated into appropriate wells (5 wells per dilution). Each plate included a series of negative control wells containing host cells and f/2 medium. Plates were incubated under the standard growth conditions for 6 to $8 \mathrm{~d}$ and observed daily for clearing relative to the control wells. Results were scored (no. positive wells/no. wells inoculated) and used in the standard MPN formula (Clesceri et al. 1989). Plaque assay of the agents was adapted from the method of Wilson et al. (2002). We mixed $100 \mu \mathrm{l}$ volumes of serially diluted virus suspension with $0.9 \mathrm{ml}$ of 
100× concentrated (via centrifugation as above), exponentially growing E. huxleyi 88E (final host concentration $\sim 1 \times 10^{7} \mathrm{ml}^{-1}$ ) and incubated each mixture under standard growth conditions with constant illumination for $2 \mathrm{~h}$ to facilitate virus adsorption. Mixtures were then added to $3 \mathrm{ml}$ of $0.4 \%$ (w/v) electrophoresis grade agarose (Sigma, A7431) in $\mathrm{f} / 2$ medium at $40^{\circ} \mathrm{C}$. This overlay was then added to $100 \mathrm{~mm}$ Petri dishes containing pre-poured layers of $1.5 \%$ agarose in $\mathrm{f} / 2$ medium. Petri dishes were returned to the incubator and observed daily for the development of plaques in the growing host monolayers.

Virus purification/concentration. Isolates that produced plaques on host monolayers underwent 2 rounds of plaque purification. Briefly, plaques were 'picked' with a sterile needle and inoculated into fresh, exponentially growing cultures of Emiliania huxleyi strain 88E. Following lysis of the host ( 3 to $4 \mathrm{~d}$ ), viruses were assayed by the plaque method, with resulting plaques picked and inoculated into fresh host cultures. Plaquepurified isolates were maintained in cultures transferred at biweekly intervals, as well as in frozen $\left(-72^{\circ} \mathrm{C}\right)$ and refrigerated $\left(4^{\circ} \mathrm{C}\right)$ stocks. For the production of highly purified virus concentrates, $500 \mathrm{ml}$ volumes of exponentially growing host $\left(\sim 1 \times 10^{5} \mathrm{ml}^{-1}\right)$ were inoculated with viruses at a multiplicity of infection (MOI) of 1.0 and incubated as described previously. Upon collapse (lysis) of the host culture, the lysates were clarified by low speed centrifugation $(2600 \times g$ for $25 \mathrm{~min}$ at $4^{\circ} \mathrm{C}$ ) in an IEC Centra Benchtop Centrifuge (Model GP8R) and filtered through a $0.22 \mu \mathrm{m}$, fetal calf serumtreated filter. Resulting filtrates were centrifuged $\left(361000 \times g\right.$ for $1.5 \mathrm{~h}$ at $\left.4^{\circ} \mathrm{C}\right)$ in a Beckman L8-75 Ultracentrifuge (Type 70.1Ti rotor). Virus pellets were resuspended in $10 \mathrm{ml}$ of virus-free seawater (prepared as descibed in the section 'Virus infectivity studies in GOM water samples' below) and further purified by cesium chloride density gradient ultracentrifugation (1.3 to $1.7 \mathrm{~g} \mathrm{ml}^{-1}$ density range) at $160000 \times \mathrm{g}$ for $2 \mathrm{~h}$ at $10^{\circ} \mathrm{C}$ (Type SW 40Ti rotor). Resulting visible bands were removed by syringe and the cesium dialyzed against dilute phosphate-buffered saline (PBS). SYBR Green I staining of purified concentrates revealed very large numbers of submicron-sized fluorescent particles similar to those seen in lysates.

Morphological studies. Aliquots $(5 \mathrm{ml})$ of purified isolate were further concentrated by ultracentrifugation at $192000 \times g$ for $2 \mathrm{~h}$ at $4^{\circ} \mathrm{C}$ (Type SW 50.1 rotor), with resulting pellets resuspended in $0.5 \mathrm{ml}$ of virusfree seawater. We then placed $10 \mu$ l concentrate volumes on 200 mesh, formvar/carbon-coated copper grids (Ted Pella) for $\sim 45 \mathrm{~min}$. Excess sample was wicked off, and grids were allowed to air dry. Grids were stained with saturated $(\sim 3 \% \mathrm{w} / \mathrm{v}), 0.2 \mu \mathrm{m}$-filtered uranyl acetate (Electron Microscopy Sciences) for $5 \mathrm{~s}$ and viewed on a Philips EM 201 transmission electron microscope.

Ether sensitivity. Isolates were tested for sensitivity to ethyl ether to determine whether a lipid envelope was present. Virus lysate ( $2 \mathrm{ml}$ volumes) was treated with $0.5 \mathrm{ml}$ ethyl ether (Fisher Scientific), vortex-mixed for $10 \mathrm{~s}$ and refrigerated at $4^{\circ} \mathrm{C}$ for $1 \mathrm{~h}$. Ether was then removed by evaporation $(\sim 1 \mathrm{~h})$ and the sample serially diluted in f/2 medium and assayed using the MPN method. Controls, which included untreated virus and ether-treated $\mathrm{f} / 2$, were similarly diluted and assayed.

Virus survival at $-\mathbf{7 2}^{\circ} \mathbf{C}$. Virus isolates were tested for stability during frozen storage. Fresh, $100 \mathrm{ml}$ virus lysates were supplemented with $10 \% \mathrm{v} / \mathrm{v}$ DMSO, divided into $5 \mathrm{ml}$ aliquots and stored at $-72^{\circ} \mathrm{C}$ in a Revco ultralow temperature freezer. At intervals, an aliquot was removed and assayed via the MPN method. Resulting virus titers were compared to those of the initial, unfrozen lysate samples.

Host range studies. We added $1 \mathrm{ml}$ volumes of fresh virus lysate $\left(\sim 10^{7}\right.$ to $\left.10^{8} \mathrm{ml}^{-1}\right)$ to $14 \mathrm{ml}$ of exponentially growing cultures of Emiliania huxleyi strains CCMP 370, 373, 374, 378, 379 and 1516, Synechococcus strain CCMP 1333 and Micromonas pusilla strains CCMP 1195 and 1545. Also tested were cultures of E. huxleyi strain 02E (clones f6 and f11), previously isolated from the GOM transect area in 2002. Once inoculated, cultures were incubated under the appropriate growth conditions and observed for signs of host lysis (versus uninoculated control cultures) for 3 to $4 \mathrm{wk}$.

One-step growth with virus 28. Exponentially growing Emiliania huxleyi 88E host cells were concentrated via centrifugation $\left(5800 \times g\right.$ for $20 \mathrm{~min}$ at $\left.4^{\circ} \mathrm{C}\right)$ and resuspended in a $25 \mathrm{ml}$ volume of $\mathrm{f} / 2$ medium to a final concentration of $4.3 \times 10^{6} \mathrm{ml}^{-1}$. Host concentrates were then either inoculated with sufficient virus 28 ( $\phi 28)$ stock to give an MOI of 1.0 (experimental flasks), or left uninoculated (control flasks). Suspensions were incubated $1 \mathrm{~h}$ under standard growth conditions (full light) to facilitate virus adsorption, and then added to $500 \mathrm{ml}$ Erlenmeyer flasks containing $225 \mathrm{ml}$ of $\mathrm{f} / 2$ medium. Samples from control and experimental flasks were collected over a $36 \mathrm{~h}$ period, with host and virus levels determined by hemacytometer and SYBR Green I counts, respectively. Chlorophyll levels (as fluorescence intensity units, FIU) were analyzed using a Turner Quantech Digital Filter Fluorometer (Barnstead International) fitted with NB 440 excitation and SC665 emission filters.

Virus infectivity studies in GOM water samples (ф28). The effects of reduced MOI and decreasing virus and host concentrations on virus infectivity patterns were also investigated. Both studies were conducted in seawater previously collected from the GOM, and used purified stocks of one of the viruses recovered during 
the present study (\$28). We used ambient seawater, rather than growth medium, to better replicate the prevailing conditions (e.g. macro- and micronutrient conditions) existing in the GOM. Prior to the experiments, the seawater was prefiltered $(0.22 \mu \mathrm{m})$ to remove bacteria and eukaryotic organisms and then rendered virus-free by ultrafiltration (Pall, Omega 50K Dalton, open channel Mini-Ultrasette), followed by 2 rounds of filtration through $0.02 \mu \mathrm{m}$ filters (Anodisc 47). The latter filtration steps were needed to remove viruses that had not been sequestered during ultrafiltration. For MOI experiments, $100 \mathrm{ml}$ volumes of virus-free seawater in $250 \mathrm{ml}$ Erlenmeyer flasks were inoculated with sufficient exponentially growing Emiliania huxleyi 88E to give a host concentration of $\sim 10^{5} \mathrm{ml}^{-1}$. Experimental flasks were then inoculated with 10-fold dilutions of $\phi 28$ to yield MOIs ranging from 1.0 (i.e. 1 virus host cell $^{-1}$ ) to 0.00001 . Flasks (including virus-free host controls) were incubated for $6 \mathrm{~d}$, with daily observations of host (hemacytometer) and virus (SYBR Green I) concentrations. In the second experimental series, $100 \mathrm{ml}$ volumes of virus-free seawater were inoculated with host concentrations ranging from $10^{5}$ to $10^{1} \mathrm{ml}^{-1}$, with the MOI kept constant at 1.0. Flasks were incubated for $7 \mathrm{~d}$, with daily readings of host and virus numbers. For flasks containing very low initial host and virus concentrations (i.e. between $10^{1}$ and $10^{2} \mathrm{ml}^{-1}$ ), it was necessary to concentrate the hosts from sample aliquots by centrifugation $\left(5800 \times g\right.$ for $20 \mathrm{~min}$ at $4^{\circ} \mathrm{C}$ ) prior to counting.

\section{RESULTS AND DISCUSSION}

Three isolates (designated ф28, 29 and 30) were recovered from the initial seawater enrichments. Isolate $\phi 28$ came from the sample collected on 12 May 2004, while isolates $\phi 29$ and 30 were obtained from the sample collected on 4 June 2004. Analysis of the samples indicated the presence of low numbers of Emiliania huxleyi, as did visual observation from the ship, plus measurements of acid-labile backscattering by coccolithophores (Balch et al. 2004). Satellite-derived, true color imagery by SeaWiFS verified the absence of coccolithophore bloom conditions. This was notable, as previous reports of E. huxleyi virus isolations most often involved environments containing high concentrations of host organisms, such as in blooms (Bratbak et al. 1993, Schroeder et al. 2002, Castberg et al. 2002). We note here some more recent viral isolations from GOM samples collected as late as October 2005, when coccolithophore concentrations were well below detection limits. In every test flask, host cultures were cleared within $10 \mathrm{~d}$ (usually within $5 \mathrm{~d}$ ), and infectivity was maintained following filtration of lysate through $0.22 \mu \mathrm{m}$, serum-treated filters. Lysates exhibited a sulphurous odor, characteristic of dimethyl sulphide (Matrai \& Keller 1993), as noted previously by Wilson et al. (2002). SYBR Green I assays revealed virus-like-particle concentrations of $>10^{8}$ $\mathrm{ml}^{-1}$. MPN assays of serially diluted lysates showed concentrations of infectious particles to be in excess of $10^{8} \mathrm{ml}^{-1}$.

Plaque assays of isolates demonstrated development of circular plaques within $24 \mathrm{~h}$, but required several days for sufficient contrast in order to observe all plaques. By the fifth day, plaques were routinely observed ranging in size from 5 to $10 \mathrm{~mm}$ in diameter (Fig. 1). Plaques continued to increase in size for approximately $1 \mathrm{wk}$, sometimes attaining diameters of $15 \mathrm{~mm}$. The speed of plaque development and plaque size exhibited by these isolates was greater than those previously reported for viruses isolated from the English Channel (Wilson et al. 2002) and Norwegian coastal waters (Castberg et al. 2002). Plaque-associated viruses kept in the incubator under the described growth conditions maintained infectivity for many weeks after plaques had fully developed. Comparison assays of fresh lysates by plaque and MPN assays yielded similar virus concentrations. Infectious virus titers derived from both plaque and MPN assays of fresh lysates were similar to virus particle counts derived from SYBR Green I staining. This latter observation suggested that a high proportion of virus particles in fresh lysates were infectious, a finding in contrast to earlier work with other Emiliania huxleyi virus

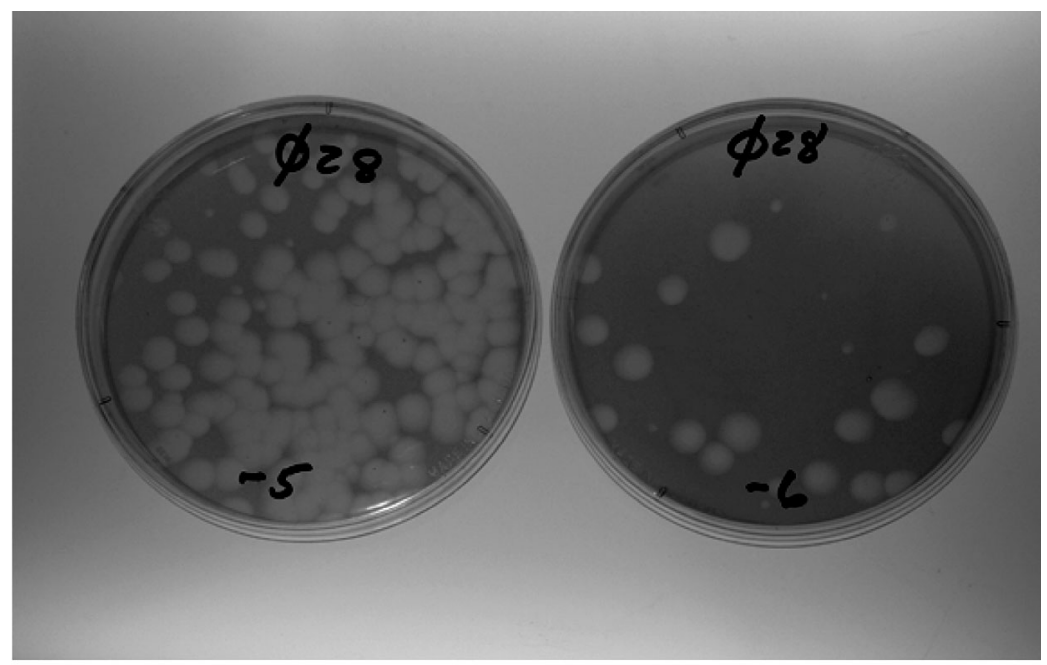

Fig. 1. Emiliania huxleyi infected with virus $\phi 28$. Virus plaques on monolayers of E. huxleyi in agarose (left to right: $10^{-5}$ and $10^{-6}$ virus stock dilutions) 
where the ratio of infectious to noninfectious particles was thought to be low (Bratbak et al. 1995, Castberg et al. 2002). Also, in contrast to earlier findings, the infectivity of isolates did not diminish with repeated (every 2 wk) passage through host cultures.

Electron microscopy of isolates revealed tailless, icosahedral structures ranging in size from 140 to $160 \mathrm{~nm}$, with electron-dense cores surrounded by what

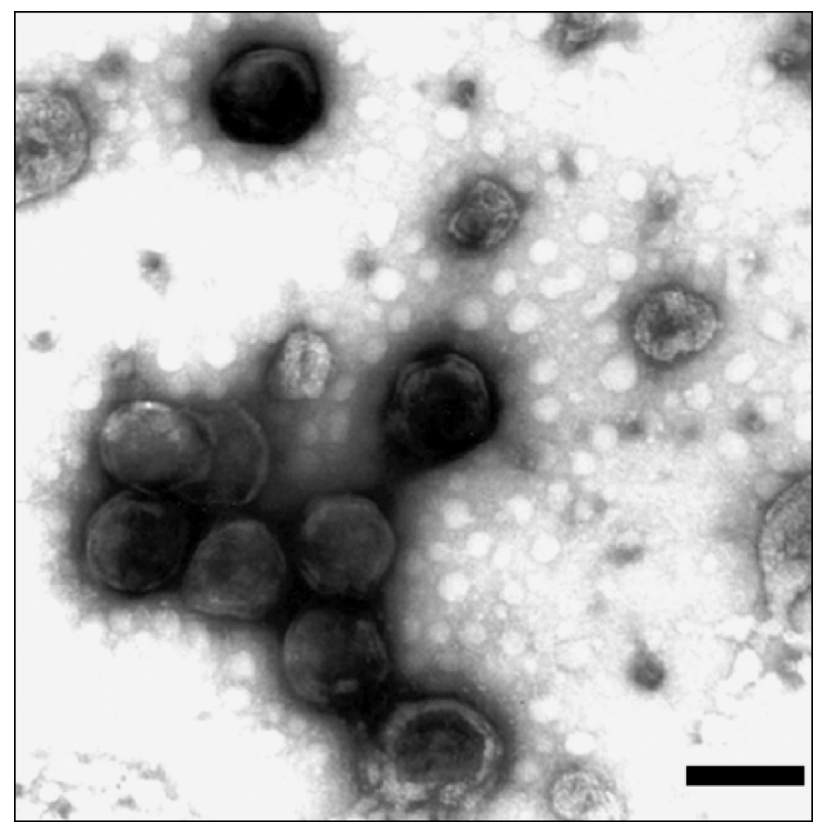

Fig. 2. Emiliania huxleyi. Transmission electron micrograph of E. huxleyi virus $\phi 28$. Scale bar $=160 \mathrm{~nm}$

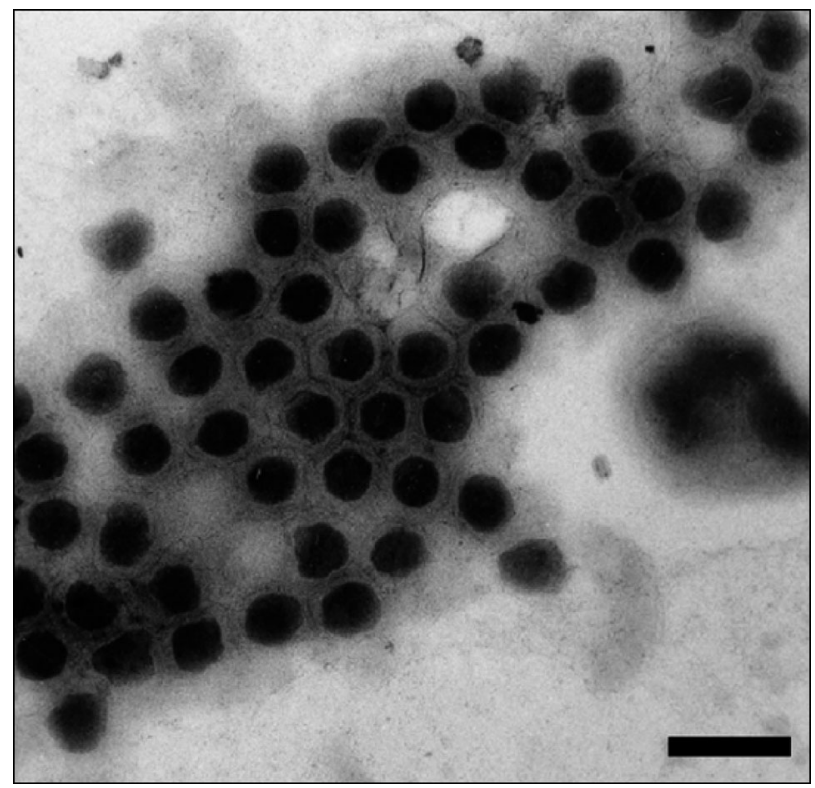

Fig. 3. Emiliania huxleyi. Transmission electron micrograph of E. huxleyi virus $\phi 30$. Scale bar $=280 \mathrm{~nm}$ appeared to be capsids (Figs. 2 \& 3). The morphologies were similar to those reported by Schroeder et al. (2002) for Emiliania huxleyi viruses isolated from the western English Channel. However, their isolates were slightly larger (170 to $200 \mathrm{~nm}$ ) than those described here.

Isolates exhibited varying levels of stability at $-72^{\circ} \mathrm{C}$. After more than $18 \mathrm{mo}$, all isolates maintained infectivity, with $41 \%$ of $\phi 28$ remaining active, followed by $\phi 30$ $(18 \%)$ and $\phi 29$ (7\%). Exposure to ether resulted in no appreciable loss of virus (compared to untreated controls), suggesting the absence of a lipid envelope.

The isolates exhibited an extremely limited host range, with no evidence of growth on any of the 7 other strains of Emiliania huxleyi tested, including 4 (CCMP $374,378,2230$ and 2231) which had originated from the GOM (Table 1). There was also no evidence of lysis or virus production on the selected strains of Synechococcus and Micromonas pusilla. In an earlier study, Castberg et al. (2002) reported considerable cross reactivity between viruses isolated during 2 separate Norwegian E. huxleyi blooms, and E. huxleyi host strains collected $10 \mathrm{yr}$ earlier from 3 different locations (coastal Norway and the North Sea). The authors logically concluded that the viruses possessed a broad host range. Similarly, Schroeder et al. (2002) tested 9 E. huxleyi virus isolates, along with 1 from coastal Norway, against $6 \mathrm{E}$. huxleyi host strains representing highly diverse environments: CCMP 370 (Oslo Fjord, Norway), CCMP 373 (Sargasso Sea), CCMP 374 (GOM), CCMP 379 (origin unknown), CCMP 1516 (South Pacific) and strain L (Oslo Fjord, Norway). All but 2 of the viral isolates infected 3 of the hosts (CCMP 374, CCMP 1516 and strain L). The remaining isolates infected at least 2 of these host strains.

Table 1. Emiliania huxleyi, Synechococcus and Micromonas pusilla. Host range study of viral isolates $\phi 28,29$ and 30 with E. huxleyi, Synechococcus and M. pusilla strains from the CCMP culture collection

\begin{tabular}{|c|c|c|c|}
\hline \multirow{2}{*}{ Host (CCMP) } & \multirow[b]{2}{*}{$\phi 28$} & \multicolumn{2}{|c|}{ iral isolates - } \\
\hline & & $\phi 29$ & $\phi 30$ \\
\hline $88 \mathrm{E}$ & + & + & + \\
\hline 370 & - & - & - \\
\hline 373 & - & - & - \\
\hline 374 & - & - & - \\
\hline 378 & - & - & - \\
\hline 379 & - & - & - \\
\hline 1516 & - & - & - \\
\hline 2230 & - & - & - \\
\hline 2231 & - & - & - \\
\hline Synechococcus 1333 & - & - & - \\
\hline M. pusilla 1195 & - & - & - \\
\hline M. pusilla 1545 & - & - & - \\
\hline
\end{tabular}


The results of virus $\phi 28,1$-step growth experiments are presented in Fig. 4. After a latent period, an abrupt rise in virus numbers $(\sim 1000 \times)$ was observed between 2.5 and $14 \mathrm{~h}$. Virus numbers then stabilized until $18 \mathrm{~h}$, when a second burst (10-fold increase) was observed through $22 \mathrm{~h}$, when counts stabilized at $\sim 10^{9} \mathrm{ml}^{-1}$ for the rest of the experiment. Host numbers did not change significantly during the initial burst and decreased only slightly during the second. As previously noted, host cultures did not clear until Day 4 ( 96 h). At this point, host counts were below detection limits (i.e. $<10^{3} \mathrm{ml}^{-1}$ ), while virus counts remained constant. Host stability during the most active period of virus replication and release, and their subsequent slow decline over the next $3 \mathrm{~d}$, suggested that viral progeny initially may have been leaking from otherwise intact host cells which did not destabilize and collapse until much later. The eventual lysis of the host was not accompanied by any significant increase in virus numbers, suggesting that most had been released earlier in the cycle. Castberg et al. (2002) reported a similar lag in Emiliania huxleyi host destruction following infection by viruses isolated from the North Sea. They attributed the lag to low numbers of infective viruses in the original inoculum, and possible hindering of infection by the presence of coccoliths. As a result, several replication cycles were required to produce sufficient virus numbers to infect and destroy a significant proportion of host cells. In the present study, the absence of coccoliths on the 88E host strain, along with the very high infection efficiencies exhibited by this virus (Fig. 6), prevented our drawing simi-

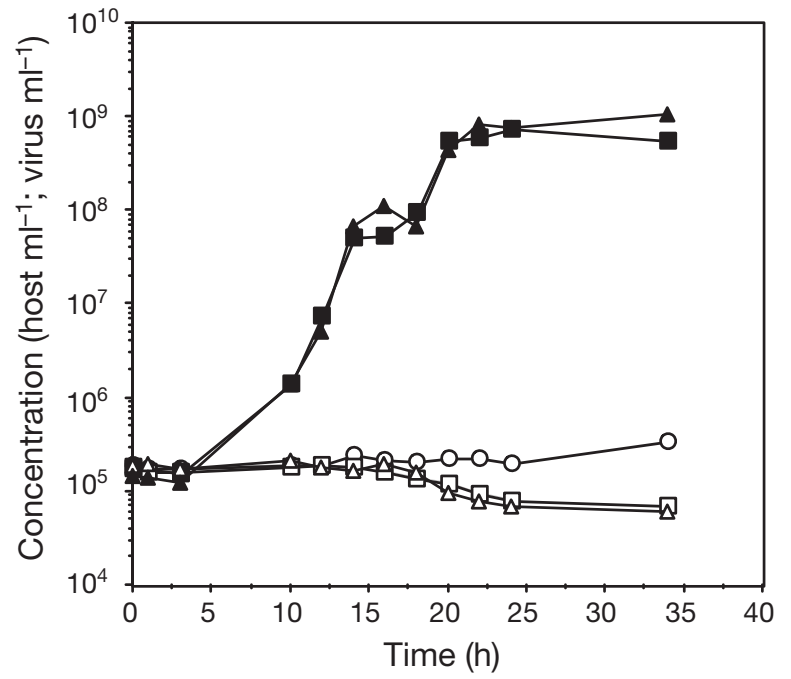

Fig. 4. Emiliania huxleyi infected with virus $\phi 28$. E. huxleyi $\phi 28$ growth curve in duplicate experimental flasks: Flask 1 (squares) and Flask 2 (triangles). (O): E. huxleyi 88E uninfected control; $(\square, \Delta)$ : 88E host cells $\mathrm{ml}^{-1} ;(\mathbf{\square}, \mathbf{\Delta})$ : virus particles $\mathrm{ml}^{-1}$ lar conclusions. Decreases in host chlorophyll fluorescence (Fig. 5) were most prominent during the primary and secondary viral bursts, suggesting that chlorophyll fluorescence was primarily lost when progeny were being released from the host.

Virus $\phi 28$ MOIs ranging from 1.0 to 0.00001 were tested on $88 \mathrm{E}$ host cells. In every case, lysates reached maximum virus levels within $2 \mathrm{~d}$ (Fig. 6), indicating that the infectious agents were highly efficient. In related experiments, the mixing of host and virus concentrations as low as $100 \mathrm{ml}^{-1}(\mathrm{MOI}=1.0)$ yielded maximum progeny numbers $\left(\sim 10^{9} \mathrm{ml}^{-1}\right)$ within $6 \mathrm{~d}$ (data not shown), further attesting to the high infectivity of the agent.

During the later stages in the preparation of the present study, studies with 2 additional virus isolates were completed, with results deemed pertinent to this work. Both isolates were recovered from the GOM using the previously described methods. Both isolates were morphologically similar to those reported above, and both were seen to propagate only on the 88E strain of Emiliania huxleyi. The first $(\phi 42)$ was isolated from a sample collected from a station at $43^{\circ} 39.92^{\prime} \mathrm{N}$, $068^{\circ} 55.509^{\prime}$ W. Virus $\phi 42$ was isolated in October 2005, a time when ambient temperatures were well below the $14^{\circ} \mathrm{C}$ optimum growth temperature for GOM $E$. huxleyi host cells (Balch et al. 1992). Virus isolations in the absence of actively growing host cells suggested that they may either possess an extended survival capacity, allowing their persistence until reestablishment of their host, or have developed a chronic infective state in what few hosts might be present. The sec-

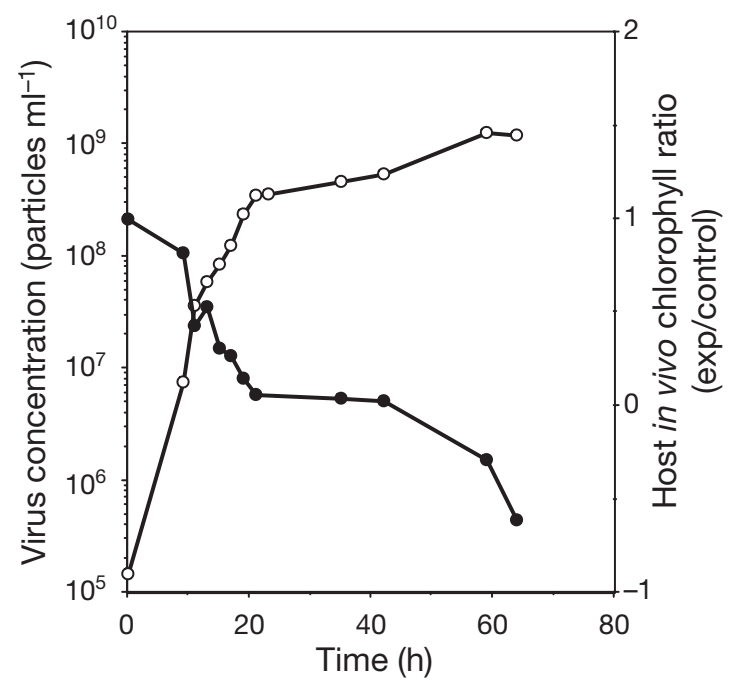

Fig. 5. Emiliania huxleyi infected with virus $\phi 28$. Virus particles $\mathrm{ml}^{-1}(\mathrm{O}$; SYBR Green I staining) and host (E. huxleyi 88E) chlorophyll fluorescence ( ; expressed as the ratio of experimental (exp):control in vivo fluorescence readings) 


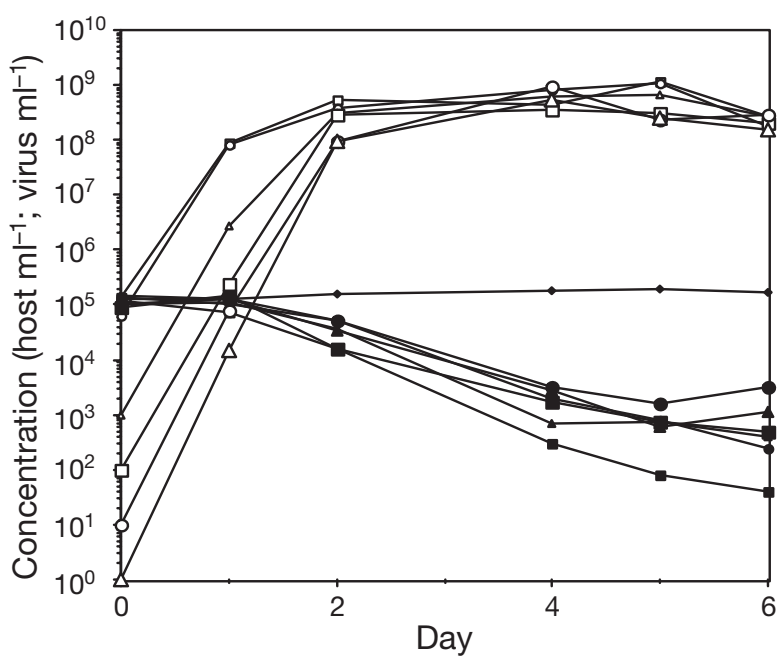

Fig. 6. Emiliania huxleyi infected with virus $\phi 28$. Effects of decreasing multiplicity of infection (MOI) on host and virus concentration. ( ) E. huxleyi 88E uninfected control; small squares: $\mathrm{MOI}=1.0 ;$ small circles: $\mathrm{MOI}=0.1$; small triangles: MOI $=0.01$; large squares: $\mathrm{MOI}=0.001$; large circles: MOI $=0.0001 ;$ large triangles: $\mathrm{MOI}=0.00001$. Filled symbols represent the host and open symbols the virus

ond isolate, $\phi 43$, recovered from a sample collected during late September $2006\left(43^{\circ} 41.01^{\prime} \mathrm{N}, 067^{\circ} 11.53^{\prime} \mathrm{W}\right)$, presented a rather unique growth cycle. Growth studies revealed that virus progeny were released beginning at $\sim 1.5 \mathrm{~h}$ post-infection (Fig. 7), and host lysis had begun within 5 h. By 18 to 20 h, clearing of the host culture had occurred, making this the most rapid lytic cycle encountered for any E. huxleyi virus, or nearly any viruses infecting eukaryotic marine algae.

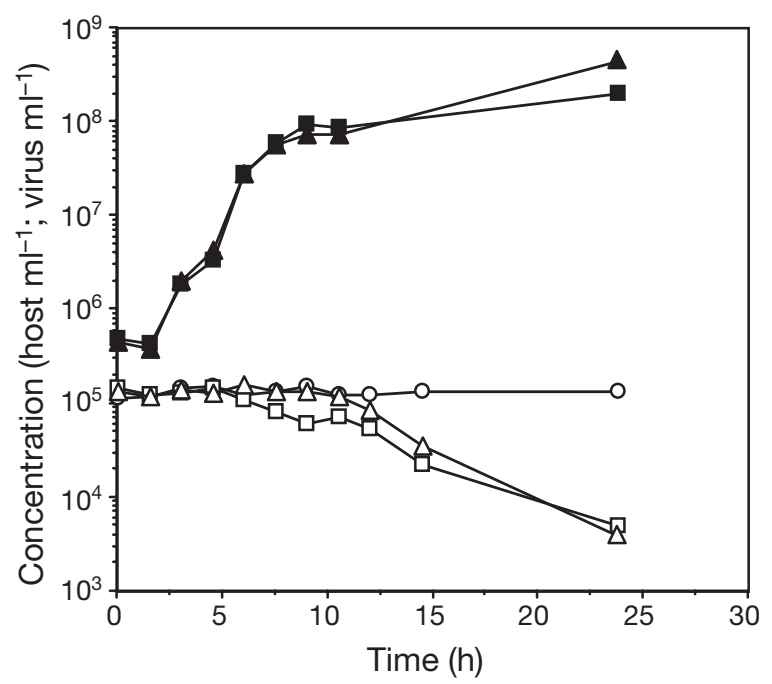

Fig. 7. Emiliania huxleyi infected with virus $\phi 43$. Growth of the virus in duplicate experimental flasks: Flask 1 (squares) and Flask 2 (triangles). (O): E. huxleyi 88E uninfected control;

$(\boldsymbol{\square}, \mathbf{\Delta})$ : virus particles $\mathrm{ml}^{-1} ;(\square, \Delta): 88 \mathrm{E}$ host cells $\mathrm{ml}^{-1}$
Since the pioneering work of Bratback et al. (1993), many studies have described the isolation and characterization of Emiliania huxleyi-specific viruses. Most of these isolates were recovered during naturally occurring or mesocosm-based host blooms in Norwegian waters, the North Sea and the English Channel. The present study describes the isolation of E. huxleyi viruses from the waters of the GOM during periods when available host cells were well below bloom levels. While morphologically similar to the previously isolated strains, these isolates were highly hostspecific, infecting only the 88E strain of E. huxleyi. Furthermore, the GOM isolates were notably stable at $-72^{\circ} \mathrm{C}$ for extended periods $(18 \mathrm{mo})$. Growth studies with virus isolate $\phi 28$ revealed considerable virus progeny release during the first $24 \mathrm{~h}$ post-infection, a period when host chlorophyll fluorescence levels also decreased, but host numbers remained stable. Subsequently, viral numbers did not increase appreciably, even when the host culture eventually cleared. These findings led us to speculate that early in the infection process, most of the progeny were leaked from the intact host, rather than released in a single burst upon host lysis. Repeated passage through host cells did not appear to diminish infectivity over an extended time period. Studies with the $\phi 28$ isolate showed the agent to be a most efficient pathogen, even at low multiplicities MOIs (0.00001) and reduced virus and host concentrations $\left(\sim 100 \mathrm{ml}^{-1}\right)$, a characteristic which would be most helpful in the maintenance of viruses during non-bloom periods and undoubtedly an important inhibitor of E. huxleyi growth during non-bloom conditions, i.e. the vast majority of the time.

Acknowledgements. This work was funded by grants from the National Aeronautics and Space Administration (no. EP02-14) and the Office of Naval Research (no. N000014-05-10111).

\section{LITERATURE CITED}

Balch WM, Holligan PM, Ackleson SG, Voss KJ (1991) Biological and optical properties of mesoscale coccolithophore blooms in the Gulf of Maine. Limnol Oceanogr 36:629-643

Balch WM, Holligan PM, Kilpatrick KA (1992) Calcification, photosynthesis and growth of the bloom-forming coccolithophore, Emiliania huxleyi. Cont Shelf Res 12:1353-1374

Balch WM, Vaughn JM, Novotny JF, Drapeau DT, Valillancourt R, Lapierre J, Ashe A (2000) Light scattering by viral suspensions. Limnol Oceanogr 45:492-498

> Balch WM, Drapeau DT, Bowler BC, Booth ES, Goes JI, Ashe A, Frye JM (2004) A multi-year record of hydrogeographic and bio-optical properties in the Gulf of Maine: I. Spatial and temporal variability. Prog Oceanogr 63:57-98

> Balch, WM, Gordon, HR, Bowler, BC, Drapeau, DT, Booth, ES (2005) Calcium carbonate measurements in the surface global ocean based on Moderate-Resolution Imaging Spectrodiometer data. J Geophys Res Oceans 110, C07001, doi:10.1029/2004JC002560 
Balch WM, Drapeau DT, Bowler BC, Booth ES, Windecker LA, Ashe A (2008) Space-time variability of carbon standing stocks and fixation rates in the Gulf of Maine, along the GNATS transect between Portland, ME, USA, and Yarmouth, Nova Scotia, Canada. J Plankton Res 30: 119-139

Bergh O, Boersheim KY, Bratbak G, Heldal M (1989) High abundance of viruses found in aquatic environments. Nature 340:467-468

Børsheim KY, Bratbak G, Heldal M (1990) Enumeration and biomass estimation of planktonic bacteria and viruses by transmission electron microscopy. Appl Environ Microbiol 56:352-356

Bratbak G, Egge JK, Heldal M (1993) Viral mortality of the marine alga Emiliania huxleyi (Haptophyceae) and termination of algal blooms. Mar Ecol Prog Ser 93:39-48

Bratbak G, Levasseur M, Michaud S, Cantin G, Fernández E, Heimdal BR, Heldal M (1995) Viral activity in relation to Emiliania huxleyi blooms: A mechanism of DMSP release? Mar Ecol Prog Ser 128:133-142

Broecker W, Peng TH (1982) Tracers in the sea. LamontDoherty Geological Observatory, Columbia University, Palisades, NY

Brussaard CPD, Kempers RS, Kop AJ, Riegman R, Heldal M (1996) Virus-like particles in a summer bloom of Emiliania huxleyi in the North Sea. Aquat Microb Ecol 10: 105-113

Castberg T, Larsen A, Sandaa RA, Brussaard CPD and others (2001) Microbial population dynamics and diversity during a bloom of the marine coccolithophorid Emiliania huxleyi (Haptophyta). Mar Ecol Prog Ser 221:39-46

Castberg TR, Thyrhaug R, Larsen A, Sandaa RE, Heldal M, Van Etten JL, Bratbak G (2002) Isolation and characterization of a virus that infects Emiliania huxleyi (Haptophyta). J Phycol 38:767-774

Clesceri LS, Greenberg AE, Trussell RR (eds) (1989) Standard methods for the examination of water and wastewater, 17th edn. American Public Health Association, Washington, DC

Fuhrman JA (1999) Marine viruses and their biogeochemical and ecological effects. Nature 399:541-548

Gordon HR, Boynton GC, Balch WM, Groom SB, Harbour DS, Smyth TJ (2001) Retrieval of coccolithophore calcite concentration from SeaWiFS imagery. Geophys Res Lett 28:1587-1590

Guillard RRL (1975) Culture of phytoplankton for feeding marine invertebrates. In: Smith WL, Chanley MH (eds)

Editorial responsibility: Curtis Suttle,

Vancouver, British Columbia, Canada
Culture of marine invertebrate animals. Plenum Press, New York, p 29-60

Holligan PM, Viollier M, Harbout DS, Camus P, ChampagnePhilippe M (1983) Satellite and ship studies of coccolithophore production along a continental shelf edge. Nature 304:339-342

Matrai PA, Keller MD (1993) Dimethylsulfide in a large-scale coccolithophore bloom in the Gulf of Maine. Cont Shelf Res 13:831-843

Nagasaki K, Ando M, Imai I, Ishida Y (1994) Virus-like particles in Heterosigma akashiwo (Raphidophyceae): a possible red tide disintegration mechanism. Mar Biol 119: 307-312

> Noble RT, Fuhrman JA (1998) Use of SYBR Green I for rapid epifluorescence counts of marine viruses and bacteria. Aquat Microb Ecol 14:113-118

> Schroeder DC, Oke J, Malin G, Wilson W (2002) Coccolithovirus (Phycodnaviridae): characterization of a new large dsDNA algal virus that infects Emiliania huxleyi. Arch Virol 147:1685-1698

> Schroeder DC, Oke J, Hall M, Malin G, Wilson W (2003) Virus succession observed during an Emiliania huxleyi bloom. Appl Environ Microbiol 69:2484-2490

- Sieburth JM, Johnson PW, Hargraves PE (1988) Ultrastructure and ecology of Aureococcus anophagefferens gen. et sp. nov. (Chrysophyceae): the dominant picoplankter during a bloom in Narragansett Bay, Rhode Island, summer 1985. J Phycol 24:416-425

Suttle CA, Chan AM (1993) Marine cyanophages infecting oceanic and coastal strains of Synechococcus: abundance, morphology, cross-infectivity and growth characteristics. Mar Ecol Prog Ser 92:99-109

Suttle CA, Chan AM (1994) Dynamics and distribution of cyanophages and their effect on marine Synechococcus spp. Appl Environ Microbiol 60:3167-3174

Suttle CA, Chan AM, Cottrell MT (1990) Infection of phytoplankton by viruses and reduction of primary productivity. Nature 347:467-469

Thierstein HR, Young JR (2004) Coccolithophores: from molecular processes to global impact. Springer-Verlag, Berlin

Waterbury JB, Valois FW (1993) Resistance to co-occurring phages enables marine Synechococcus communities to coexist with cyanophages abundant in seawater. Appl Environ Microbiol 59:3393-3399

Wilson W, Tarran GA, Schroeder D, Cox M, Oke J, Malin G (2002) Isolation of viruses responsible for the demise of an Emiliania huxleyi bloom in the English Channel. J Mar Biol Assoc UK 82:369-377

Submitted: October 21, 2008; Accepted: September 5, 2009 Proofs received from author(s): December 17, 2009 